\title{
Integration of Financial Markets in Post Global Financial Crises and Implications for British Financial Sector: Analysis Based on A Panel VAR Model
}

\author{
Muhammad Ali Nasir ${ }^{1}$. Min Du ${ }^{2}$
}

\begin{abstract}
This study analyses the dynamics of integration among global financial markets in the context of Global Financial Crisis (2008) by employing a Panel Vector Autoregressive (VAR) model on the monthly data of nine countries and three markets from Jan 2003 to Oct 2015. It was found that there has been a shift in the association among the global financial markets since Global Financial Crisis (GFC). Moreover, the British financial sectors in Post- GFC world clearly showed a change in the association with the global financial sectors. Particularly, the emerging markets including China, Brazil and India showed a comparatively more significant impact on the UK financial sector implying the increased importance of the latter in the recent past. The German and USA financial sector also showed a change in its impact in the Post-GFC world. It showed that Germany and USA financial sectors have become competitive to the UK financial Sector as the surge in them lead to a relative response from the UK financial sector which could be associated with the portfolio adjustment.
\end{abstract}

Keywords Financial markets · Financial integration · Global financial crises · Panel VAR model

JEL Classification $\mathrm{G} 10 \cdot \mathrm{G} 15 \cdot \mathrm{F} 31 \cdot \mathrm{P} 45$

$凶 \quad$ Muhammad Ali Nasir

m.a.nasir@leedsbeckett.ac.uk

1 School of Accounting, Finance and Economics, Faculty of Business and Law, Leeds Beckett University, The Rose Bowl, Portland Crescent, Leeds LS1 3HB, UK

2 Faculty of Business and Law, Leeds Beckett University, Leeds, UK 


\section{Introduction}

In the wake of financial crises, a number of studies have emphasised the importance of financial markets for the national and global economies. There is also emphasis on the policy measures whether macroeconomic policy measure supported by Williams (2012), Blanchard et al. (2010) Mishkin (2011) and Nasir and Soliman (2014) or studies for instance by Angelini et al. (2012) Benigno et al. (2012) Mishkin (2011) which support the idea of prudential policies. However, the policy debate is infinitely perpetual as there are also arguments against the role of macroeconomic and prudential policies in the stable functioning of financial markets (See Benigno et al. 2013 Agenor et al. (2011) and Borio (2011), Svensson (2012) and Collard et al. (2012). Nevertheless, there have been some unconventional instruments of asset purchases (Quantitative Easing or Q.Es) used and there have been changes in the supervisory and institutional architects of the financial system by which we mean formulation of institutions like Financial Policy Committee and Prudential Regulatory Authority (PRA) at the Band of England. On the aspect of the Q.Es there is some critique in the literature by Mishkin (2011) and Curdia and Woodford (2011) asserting that Q.Es are not very effective in addressing financial crises, whereas on the effectiveness of institutional changes, although the importance of institutional structure is acknowledged studies, for instance, Lu and In (2006) and Semiromi and Reza (2010), any comments would be predated and perhaps time would be the best judge on the performance of the respected institutions.

A Corollary to the above para, the sole purpose of which is to set the scene and provide the context, in which the very purpose of this treatise is neither to go into the role of policy in financial markets performance nor the efficiency and effectiveness of institutions and institutional architect. Perhaps, the caveat we are addressing in this study is looking beyond the boundaries and scope of national policies and institutions in terms of their influence on financial markets by investigating the dynamics of financial markets (stock, bonds and forex) linkages in the wake of Global Financial Crisis (GFC). We are particularly interested in investigating how the association between the domestic and international financial markets has been changed over the GFC 2008. The financial crisis which was said to be a global phenomenon and the financial contingent spread across the world affecting almost every financial market, the question it raises is whether the relationship between financial markets in the Post-GFC world has been dampened or strengthened. Perhaps, we have witnessed the changes in the behavior of financial markets after major crises and events in response to policy measures. For instance, an investigation of stock markets by Wong et al. (2005) showed that markets have become more efficient after the financial crisis of 1987 (Black Monday) and 1997 (Asian Financial Crisis) as the relationship between stock markets and macroeconomic variables has become weaker. Concomitantly, if that thesis is to be believed by having faith in the increase of market efficiency due to adverse shock and financial crisis, should there be an increase in efficiency due to GFC 2008? Perhaps, which is considered to be one in a century financial crisis ${ }^{1}$ or what implications could

\footnotetext{
1 There is consensus that Global Financial Crisis (2008) was the worst financial crisis since 1929s, https:// www.imf.org/external/np/sec/pn/2009/pn0997.htm.
} 
it have for the global financial linkages or the association and integration among the global financial markets?

In the existing evidence on the subject of GFC's impact, a shift in the association between monetary policy and stock markets in the light of the GFC was investigated by Kontonikas et al. (2013). It showed that the financial crisis of 2007-8 lead to a change in the association between the stock market and monetary policy in the US as the impact of monetary policy expansion became positive to neutral after financial crisis. In earlier studies on this aspect, Berger and Bouwman (2012) showed that in USA, the financial (Banking) sector response to monetary policy in Pre-Dot com bubble period was limited to the small and medium banks; nevertheless, they found that the effect of monetary policy on the financial (Banking) sector decreased during and after the crisis. In specific to the stock market, Wang and Mayes (2012) found a significant negative stock price reaction to monetary policy surprises in the Pre-financial crisis in UK, EU, New Zealand and Australian stock markets, but they found that the UK and euro area responses to both expected and surprise rate change components become positive during the crisis. In contrast, the New Zealand and Australian stock responses remained negative during the crisis. There could be a number of reasons to explain the shift in the response of stock market to monetary policy action and heterogeneity in the response of different stock markets ${ }^{2}$, yet the change in the behavior of stock market is prima facie. Perhaps, further support to this notion comes from the Swiss financial sector where a study by Fischbacher et al. (2012) also reported a shift in the association between financial markets (stock and bond) and monetary policy after financial bubbles. Hence, in the light of these studies, it is plausible to establish that the major macroeconomic or financial events like GFC could lead to the change in response of financial markets. Concomitantly, this notion, fuels the rationale of our study by stressing the questions that if that is the case, how financial markets (Stock, Bonds and Forex) interlink and behavior to each other's dynamics might have changed due to GFC ?.

On the integration of global financial markets in terms of co-movements, we do not have much evidence to cite, yet there is some empirical evidence on the comovement of stock markets in response to the monetary policy shock, for instance the study by Ioannidis and Kontonikas (2008) reported an increased co-movement of international stock returns. They argued that this relationship has grown stronger particularly after January 1999 (Common monetary policy by European Central Bank). Similar claims were made by Kizys and Pierdzioch (2009), particularly for European countries. The different impact of the same factor on different stock markets indicates the asymmetric response of the stock market to macroeconomic shocks. On similar grounds, a study by Gupta and Guidi (2012) on the links between the Indian stock market and developed Asian markets (Hong Kong, Japan and Singapore) found that there is a short-run relationship and absence of a strong long-run relationship among these markets. Moreover, in a recent endeavor, Nashier (2015) found elements of

\footnotetext{
2 They associated it with Zero Lower bound (ZBL) on interest rates and argued that this effect is amplified during the zero bound period. The rationale for the divergence in the NZ and AU was due to the fact that the NZ and AU policy rates did not reach the zero bound.
} 
association between BRICS ${ }^{3}$ and UK and US stock markets in the period from 20042013, although they did not look at any structural break in the relationship due to financial crises and looked at the association as a whole which might be different in the Post-GFC (2008) world. Perhaps if there is no difference it would imply that market behavior has not changed nor its participants behavior towards other markets. However, this is the venue yet to explore and foci of this treatise.

On the aspect of financial integration in the European countries in the light of Feldstein-Horioka (FH) theory, ${ }^{4}$ a study by Choudhry et al. (2014) found that there is an increase in the disintegration in the European Union (EU) countries in Post-GFC. Whereas a study by Georgoutsos and Migiakis (2013) reported a slow mean-reverting process in the sovereign bond yield spreads for 10 Economic and Monetary Union (EMU) countries against the German Bund. Hence, the integration or at least its pace in the EMU is questionable and has implications in terms of GFC. On fairly similar lines, a study on the association between frontier ${ }^{5}$ and leading markets Chen et al. (2014) reported that the frontier stock markets are affected by leading stock markets particularly the US market, however there where some stock markets i.e. African and Middle east markets which did not show major influence by the leading markets. Nevertheless, the idiosyncratic nature of this study is its focus on the association among global financial markets included stock, sovereign bonds and Forex markets and particularly the aftermath of GFC. Starting from the global financial markets, we took a general to specific approach and narrowed down our analysis to UK financial markets. GFC and Lehman Brother's bankruptcy (2008) severely hit global as well as the British financial markets. In specific to the British financial markets Gregoriou et al. (2009) found a structural break in the response of the stock market to monetary policy in the post-financial crisis (2008) period. Concomitantly, it raises questions whether the association between British financial markets and major global financial markets has also been changed due to the financial crises and if so there could be policy implications as well as investment strategies. Nevertheless, focusing on the British financial sector is also due to its global significance, perhaps this is the reason it has been put top of the list in the Global Financial Centre Index (GFCI 2016).

The key findings of our analysis based on a Panel VAR Model suggested that there has been a shift in the association among the global financial markets since GFC. Moreover, the National financial structure in Post- GFC era clearly showed a change in the association among the financial sectors. Particularly, the emerging markets including China, Brazil and India showed a comparatively more significant impact on the UK financial sector implying the increased importance of the latter in the recent past. The German and USA financial sector also showed a change in its impact in

\footnotetext{
3 Brazil, Russia, India, China and South Africa.

4 According to this theory if investors are able to easily invest anywhere in the world, acting rationally they would invest in countries that offer the highest return per unit of investment. This would drive up the price of the investment until the return across different countries is similar. See Feldstein and Horioka (1980) for further details.

5 FM countries include: Argentina, Bahrain, Bangladesh, Bulgaria, Croatia, Estonia, Jordan, Kenya, Kuwait, Lebanon, Lithuania, Kazakhstan, Mauritius, Morocco, Nigeria, Oman, Pakistan, Romania, Serbia, Slovenia, Sri Lanka, Tunisia, Ukraine and Vietnam, Source (MSCI 2015) https://www.msci.com/resources/ factsheets/index_fact_sheet/msci-frontier-markets-index.pdf.
} 
the Post-GFC world. It showed that Germany and USA financial sectors have become competitive to the UK financial Sector as the surge in them lead to a relative response from the UK financial sector which could be associated with the portfolio adjustment.

The paper proceeds as follows, "Methodology" section 2 briefly sets out the layout of the empirical framework and Panel VAR model as a mean to analyse the association among under analysis variables, "Empirical Data" section will provide the details on empirical data and sampling information, "Findings and Analysis" section present the findings and "Conclusions and Implications" section, entails conclusions and discussion on the implications.

\section{Methodology}

To analyse the data and investigate the association among under-analysis variables of interest a Panel Vector Autoregressive model is employed. The novelty of the VAR framework is that the endogenous and explanatory variables interact simultaneously, hence there is extended information set, which makes it a better presentation of the economic system (Pecican 2010). To start with, the Chow test is used to find out if there is a structural break coinciding with the GFC period. To clarify this procedure, let's consider the following equation:-

$$
Y_{t}=\alpha 1+\beta_{i} X 1_{t-i}+\beta_{i} X 2_{t-i}+\varepsilon_{t}
$$

According to Chow (1960), if we split the sample into before and after period under focus, the null hypothesis states that the coefficient of regression analysis in both sub-periods should be equal to coefficients of total period. Hence, in the absence of a structural break, $\alpha 1=\alpha 2, \beta_{i} X 1_{t-i}=\beta_{i} X 1_{t-2}$ and $\beta_{i} X 2_{t-i}=\beta_{i} X 2_{t-2}$ and so on.

In order to proceed with the causal analysis, we need to satisfy the condition of stationarity by performing a Unit Root test. A proposed method could have been Augmented Dickey and Fuller (ADF) test, however, given that we are considering the possibility of a structural break in earlier mentioned Chow test which may pose a question on the robustness of our findings if the ADF method is employed. In this respect, Perron (1989) cautioned that ADF test could give biased results. On theoretical grounds, a very important point we must elaborate here is that financial assets, for example, stock or bond prices data series exhibit a structural change from their usual trend due to various reasons, for instance, macroeconomic policy decisions or financial and economic events. Making this point as a base, some studies like Ranganathan and Ananthakumar (2010) criticised that the ADF test is biased towards null of random walk in presence of such a structural break in a series. The reason was given that in case of not accounting for structural breaks, the random shocks are assumed to have a permanent effect on the system. Concomitantly, an essential feature of this paper is that we are considering the structural breaks, hence it would help us test whether these shocks are just transitory around a stable trend path. To overcome this potential flaw in the ADF test and its theoretical and practical implications, this study will adopt the Levin et al. (2002), Im et al. (2003) and Fisher type i.e. ADF-Fisher Chi-square and PP-Fisher Chi-square tests. These tests are useful for the small sample as well for 
the heterogeneous panels. Nevertheless, the panel unit-root tests offers higher power than the unit root tests based on time series. (For further discussion and comparative analysis on the performance and choice of unit root tests, please see Maddala and Wu (1999) and Choi (2001) and Hadri (2002). The lag sections test would be performed and a number of information criteria including Akaike information criterion (AIC), Schwarz information criterion (SIC) and Hannan-Quinn information criterion (HQ) will be employed to decide on the optimal numbers of lags to be included in the model. The selection of an optimal number of lags will lead to the co-integration analysis to find whether the variables are co-integrated, i.e. if they have a long-run association among them. In case there is a co-integration or long run association among variables, the study will employ a Vector Error Correction (VEC) model which is a restricted form of Vector Autoregresive model. The basic feature of VEC model is that it includes an error correction term $\left(U_{t-1}\right)$ which is a one period lagged residual term and guides or restores the system to equilibrium. The Pedroni Residual Cointegration approach will be used for the Panel cointegration test. The choice of this approach towards co-integration testing is due to the reason that it provides asymptotic distributions for test statistics that are appropriate for various cases with heterogeneous dynamics, endogenous regressors, fixed effects, and individual-specific deterministic trends. Nevertheless, it also includes tests that are appropriate both for the case with common autoregressive roots under the alternative hypothesis as well as tests that permit heterogeneity of the autoregressive root under the alternative hypothesis (For detailed discussion please see, Pedroni 1999). The model will be estimated using Least Squared method and also robustness of the model will be tested further in the diagnostic analysis which includes Heteroscedasticity, Autocorrelation tests. The estimation results often show that various values of lagged explanatory variables have differing signs and sizes of impact on response variables. Therefore we will perform the Impulse Response Function (IRF) analysis. The IRFs are obtained from the Moving Average (MA) representation of the original VAR model. The IRFs are the dynamic response of each endogenous variable to a one-period standard deviation shock to the system. As Brooks (2008) described the responsiveness of the dependent variables in the VAR to shocks on each variable is revealed by the Impulse responses. So, for each variable from each equation separately, a unit shock is applied to the error, and the effects upon the VAR system over time are noted. In other words, a shock to the $i t h$ variable directly affects the ith variable and in addition, is transmitted to the other endogenous variables through the dynamic lag structure of the Panel VAR model. Concomitantly, the IRF analysis traces out the effects of one time shock to one of the innovations of the current and future values of the endogenous variables. In specific to subject study it will also help us to get some further insight and to view a big picture of association among variables.

\section{Empirical Data}

The empirical analysis consist of monthly data on 9 major stock markets of the world including New York Exchange (USA), London Stock Exchange (UK), Frankfurt Stock Exchange (Germany), Shanghai Stock Exchange (China), Tokyo Stock Exchange 
(Japan), Bombay Stock Exchange (India), Sao Paulo Stock Exchange (Brazil), Sydney Stock Exchange (Australia) and Toronto Stock Exchange (Canada). The choice of these markets is based on their capitalisation and the chosen stock markets are 9 of the top stock markets in the world by the size of their capitalisation. ${ }^{6}$ Nevertheless, their associated economies are also 9 of the largest economies in the world. To represent the stock markets, monthly averages of the indexes were used which included Dow Jones Industrial Average (New York), FTSE-100 index (London), Deutsche Boerse DAX Index (Frankfurt), SSE Composite Index (Shanghai), Nikkei 225 Index (Tokyo), S\&P BSE Sensex Index (Bombay), Sao Paulo SE Bovespa Index (Sao Paulo), S\&P/ASX 200 Index (Sydney) and TSX-Toronto Stock Exchange 300 Composite Index (Toronto).

The real yield on sovereign bond of under analysis countries was used as a proxy to represent the bond markets. The monthly average of the real yield on the 10 years government bond was chosen which is inverse of bond's price; it was due to the fact that real yield is very important for the economic agents participating in the bonds markets (Campbell 1995). Nevertheless, the real yield on the sovereign bonds is also important as it represents its borrowing cost for the government; it also reflects the confidence of markets participants and investors in bonds and importantly returns on investment (Nasir et al. 2016). The data on the bond yield is not logged because it is a percentage and also negative real yield cannot be logged.

The third variable of interest is the foreign exchange markets. In order to incorporate the foreign exchange markets into analysis this study employed the Real Effective Exchange Rate (REER) of the under analysis countries' currencies. The real effective exchange rate (REER) is the weighted average of a country's currency relative to an index or basket of other major currencies. The weights are determined by comparing the relative trade balance of a country's currency against each country within the index. The REER is superior to the Nominal Effective Exchange Rate (EER) as it is adjusted for the effects of inflation. The data on the REER is not logged as it was the rate. The data included the monthly averages of the REER indexes. All the data observations from January 2003 to October 2015 were obtained from the Thomson Reuters database "Datastream". The descriptive statistics of the under analysis data are presented in the Tables 5 and 6 (Appendix "A") for the interest of readers.

Our analysis is twofold, at first ("Global Financial Markets" section) we will consider the association among the global financial markets i.e. Stock, Sovereign Bonds and Forex markets. For this purpose we used the dataset of nine countries representing each market. Putting it simply, we have three variables i.e. the global stock, global bond and global forex markets, each of them constitute the data of nine countries on each. Hence, we have 9 cross-sections and three series, each series presenting one of the market (stock, bond or Forex) and entailing 9 cross-sections entailing data on each country's market. The association among these three markets in the Pre and PostGFC periods will be analysed. In the second fold ("Integration of National Financial Structure" section) we will flip the sequence where we will have nine countries i.e. 9 series with their respective financial sector (each constituting 3 markets i.e. 3 crosssections). Doing so, will lead us to analyse the association among the financial sector

6 "All of the World's Stock Exchanges by Size". The Money Project. Available at http://money. visualcapitalist.com/all-of-the-worlds-stock-exchanges-by-size/. 
of the Britain (constituting stock, bond and forex markets) with the under analysis financial sectors of the remaining eight countries.

\section{Findings and Analysis}

\section{Global Financial Markets}

To start with the association among the global financial markets, i.e. the stock, bond and forex markets is analysed by employing the panel data of nine countries on three financial markets. Our Panel VAR model will take the form of following simultaneous equations:-

$$
\begin{aligned}
\ln \text { Stock }_{i, t}= & \alpha_{10}+\sum_{j=1}^{p} \beta_{1 j} \ln \text { Stock }_{i, t-j}+\sum_{j=1}^{p} \gamma_{1 j} \text { Bond }_{i, t-j} \\
& +\sum_{j=1}^{p} \theta_{1 j} \text { Forex }_{i, t-j}+\varepsilon_{1 i, t} \\
\text { Bond }_{i, t}= & \alpha_{20}+\sum_{j=1}^{p} \beta_{2 j} \ln \text { Stock }_{i, t-j}+\sum_{j=1}^{p} \gamma_{2 j} \text { Bond }_{i, t-j} \\
& +\sum_{j=1}^{p} \theta_{2 j} \text { Forex }_{i, t-j}+\varepsilon_{2 i, t} \\
\text { Forex }_{i, t}= & \alpha_{30}+\sum_{j=1}^{p} \beta_{3 j} \ln \text { Stock }_{i, t-j}+\sum_{j=1}^{p} \gamma_{3 j} \text { Bond }_{i, t-j} \\
& +\sum_{j=1}^{p} \theta_{3 j} \text { Forex }_{i, t-j}+\varepsilon_{3 i, t}
\end{aligned}
$$

Where lnstock, Bond and Forex are endogenous variables, $a_{10}$ to $a_{30}$ are vectors of constant terms, $\beta \gamma$ and $\theta$ are ( $\mathrm{nx}$ ) matrixes of coefficients and $\varepsilon_{1}$ to $\varepsilon_{1}$ are errors terms with assumptions of no autocorrelation and independent distribution i.e.

$$
\varepsilon_{t} \sim N(0, \sigma 2)
$$

To test whether a structural break in the relationship of under analysis variables exists around the period of GFC, Chow structural break test is performed. The results presented in Table 7 (Appendix B) showed that the null of no break was rejected as $1 \%$ level of significance. Hence, it implied that there was a shift in the relationship among the global Bond, Stock and Forex markets. To investigate the dynamics of the relationship and make comparisons between pre and Post-GFC, we followed the footsteps of Politis et al. (1999), Wong et al. (2006) by sub-sampling. The period for the Pre-GFC was from January 2003-August 2008, we considered the collapse of 
Lehman Brothers as central points of GFC (Nasir et al. 2015). Before the estimation of the model it is necessary to test for, and satisfy, the condition of stationary of the data series for the period of analysis, therefore the Panel Unit Root test is performed and results are presented in the Table 8 (Appendix B). The results summary of our stationarity test for Panel Unit Root showed that although at level there were mixed results, on the first difference $I(1)$ all the panel data was stationary which is not surprising while dealing with economic and financial data. Hence, in the Panel VAR model we will use the first differenced data. As the VAR framework requires certain numbers of lags of each variable to be included in the model, an optimal lag selection test is performed using various criteria to find how many lags be included in the model. The results of optimal lag selection test are presented in Table 9 (Appendix "B") which showed that SC and HQ criterias indicated 1 as optimal lag while the AIC, FPE and LR criterias indicated 5 as optimal lag order, therefore we chose the same (5) number of lags. The rationale for this choice is supported by Liew (2004) argument that the AIC is appropriate criteria, even for small samples. Moreover, AIC minimizes the possibility of underestimation of the optimal lag length while improving the potential that the true lag length is recovered. Nevertheless, in particular to our study the alternative suggestion of one lag was not producing best estimates, hence for robustness of analysis this study considered and incorporated 5 lags into the analysis. After optimal lag selection tests we performed the co-integration test using Pedroni Residual approach, the results are presented in the Table 10 (Appendix "B"). The results suggested that there is no co-integration relationship as the p-values were more than 0.05 ; therefore we cannot reject the null hypothesis of no co-integration. Concomitantly, the unrestricted VAR model is the suitable candidate for subject instead of a restriction VAR or VEC Model. Considering the fact that the aim of this study is to analyse the integration of financial markets over the GFC we split the under analysis period into pre-and post-financial crisis eras. This approach and practice of sub-sampling is supported and prescribe in the seminal work by Politis et al. (1999) and Wong et al. (2006).

\section{VAR Model Pre-Global Financial Crisis}

At first, we estimated the Panel VAR model i.e. Eqs. 2-4 for the Pre-GFC period using Panel Ordinary Least Squared method (Table 1).

The results of the Panel VAR model (Eqs. 2-4) estimated for the Pre-GFC period showed that there are several values of coefficients ranging from positive to negative and significant to insignificant. The t- test score parallel to each coefficient values indicates a significant impact of explanatory variables at $95 \%$ level of confidence and vice versa. Interestingly the F-test score was quite high and significant as well as the goodness of fit $\mathrm{R}^{2}$ which showed values well above $90 \%$ indicating the strength of our model. Before a comparison can be made with the Post-GFC period, it required estimating the PVAR model (Eqs. 2-4) for the Post-GFC period. 
Table 1 Panel vector autoregressive (PVAR) model M1-2003: M8- 2008

\begin{tabular}{|c|c|c|c|c|c|c|}
\hline & LNSTOCK & t-stats & BONDS & t-stats & FOREX & t-stats \\
\hline LnStock $_{t-1}$ & 1.0703 & [ 25.303] & -0.6037 & {$[-2.748]$} & 0.9754 & [ 0.810] \\
\hline LnStock $_{t-2}$ & 0.0761 & [ 1.231] & 0.8127 & [ 2.530] & -0.1608 & {$[-0.091]$} \\
\hline LnStock $_{t-3}$ & -0.1418 & {$[-2.265]$} & 0.1602 & [ 0.492] & -2.2149 & {$[-1.243]$} \\
\hline LnStock $_{t-4}$ & 0.0729 & [ 1.138] & -0.1627 & {$[-0.489]$} & -0.3815 & {$[-0.209]$} \\
\hline LnStock $_{t-5}$ & -0.0815 & {$[-1.842]$} & -0.2237 & {$[-0.974]$} & 1.7990 & [ 1.429] \\
\hline Bonds $_{t-1}$ & -0.0011 & {$[-0.144]$} & 1.0560 & [ 25.718] & 0.2077 & [ 0.923$]$ \\
\hline Bonds $_{t-2}$ & -0.0080 & {$[-0.699]$} & -0.2053 & {$[-3.440]$} & -0.2371 & {$[-0.725]$} \\
\hline Bonds $_{t-3}$ & 0.0216 & [ 1.894] & 0.2265 & [3.810] & 0.4686 & [ 1.439] \\
\hline Bonds $_{t-4}$ & -0.0047 & {$[-0.375]$} & -0.3054 & {$[-5.434]$} & -0.0366 & {$[-0.118]$} \\
\hline Bonds $_{t-5}$ & -0.0076 & {$[-1.065]$} & 0.2075 & [ 5.590] & -0.3450 & {$[-1.696]$} \\
\hline Forex $_{t-1}$ & -0.0010 & {$[-0.685]$} & 0.0043 & [ 0.558$]$ & 1.0626 & [ 24.646] \\
\hline Forex $_{t-2}$ & 0.0021 & [ 0.978$]$ & -0.0098 & {$[-0.853]$} & -0.1402 & {$[-2.214]$} \\
\hline Forex $_{t-3}$ & 0.0003 & [ 0.163$]$ & 0.0060 & [ 0.529] & 0.1275 & [ 2.024] \\
\hline Forex $_{t-4}$ & -0.0013 & {$[-0.592]$} & -0.0015 & {$[-0.136]$} & 0.0130 & [ 0.206] \\
\hline Forex $_{t-5}$ & -0.0004 & {$[-0.266]$} & 0.0012 & [ 0.160$]$ & -0.0758 & {$[-1.768]$} \\
\hline Constant & 0.0590 & [ 1.850$]$ & 0.2199 & [ 1.326] & 0.8951 & [ 0.985$]$ \\
\hline F-test & 9341.239 & $0.000 * *$ & 1750.892 & $0.000 * *$ & 4051.065 & $0.000 * *$ \\
\hline $\mathrm{R}^{2}$ & 0.996 & & 0.979 & & 0.991 & \\
\hline DW Stat. & 2.034 & & 2.058 & & 1.951 & \\
\hline Obs. (N) & 612 & & 612 & & 612 & \\
\hline
\end{tabular}

$* t$ test score in [ ]. ** Significance at $1 \%$ level

\section{VAR Model Post-Global Financial Crisis}

The results are presented in Table 2 below:

Similar to the pre-GFC period, the results of our Panel VAR model (Eqs. 2-4) estimated for the Post -GFC period showed varying values of coefficients. The t- test score parallel to each coefficient values indicates a significant impact of explanatory variables at a $95 \%$ level of confidence. Interestingly the F-test score as $\mathrm{R}^{2}$ also showed significant values indicating the predictability and strength of the model. We did perform the robustness tests against the issues of Heteroscedasticity and Autocorrelation by using the White and LM test respectively. The outcome of robustness tests supported the estimated models. ${ }^{7}$ However, the comparison of the estimates of the two period results are cumbersome and inconclusive if we base it on values of individual coefficients of the relationship of each variable and its corresponding lags, hence it required us to perform an Impulse Response Analysis to get a bigger picture.

7 The results of robustness tests are not presented to conserve the space, however are available on request. 
Table 2 Panel vector autoregressive (PVAR) Model M1-2009: M10- 2015

\begin{tabular}{|c|c|c|c|c|c|c|}
\hline & LNSTOCK & t-stats & BONDS & t-stats & FOREX & t-stats \\
\hline LnStock $_{t-1}$ & 1.006167 & [ 26.630] & 0.403445 & [ 2.522] & 1.752745 & [ 1.365$]$ \\
\hline LnStock $_{t-2}$ & -0.08146 & {$[-1.496]$} & -0.46951 & {$[-2.038]$} & -2.92497 & {$[-1.582]$} \\
\hline LnStock $_{t-3}$ & 0.1604 & [ 2.935] & 0.25657 & [ 1.109] & 3.672023 & [ 1.978] \\
\hline LnStock $_{t-4}$ & -0.10055 & {$[-1.862]$} & 0.28873 & [ 1.263$]$ & -2.17301 & [-1.184] \\
\hline LnStock $_{t-5}$ & 0.011606 & [ 0.312] & -0.4757 & {$[-3.023]$} & -0.49348 & {$[-0.390]$} \\
\hline Bonds $_{t-1}$ & -0.00538 & {$[-0.604]$} & 0.983332 & [ 26.101] & 0.263617 & [ 0.872] \\
\hline Bonds $_{t-2}$ & $-9.94 \mathrm{E}-05$ & {$[-0.007]$} & 0.032114 & [ 0.606$]$ & -0.37253 & {$[-0.877]$} \\
\hline Bonds $_{t-3}$ & 0.00745 & {$[0.616]$} & 0.02064 & [ 0.403] & -0.07519 & {$[-0.183]$} \\
\hline Bonds $_{t-4}$ & 0.003778 & [ 0.315$]$ & -0.06233 & {$[-1.228]$} & 0.582308 & [ 1.429] \\
\hline Bonds $_{t-5}$ & -0.00567 & {$[-0.657]$} & 0.02587 & [ 0.709] & -0.32197 & {$[-1.100]$} \\
\hline Forex $_{t-1}$ & 0.000853 & {$[0.760]$} & -0.00392 & {$[-0.826]$} & 1.219936 & [ 32.038] \\
\hline Forex $_{t-2}$ & -0.00146 & {$[-0.815]$} & 0.003629 & [ 0.479] & -0.2438 & {$[-4.015]$} \\
\hline Forex $_{t-3}$ & 0.001809 & [ 1.011$]$ & -0.00051 & {$[-0.067]$} & 0.060713 & [ 0.999] \\
\hline Forex $_{t-4}$ & -0.003 & {$[-1.715]$} & -0.00502 & {$[-0.678]$} & -0.11693 & {$[-1.968]$} \\
\hline Forex $_{t-5}$ & 0.001539 & [ 1.374$]$ & 0.005027 & [ 1.060] & 0.073372 & [ 1.929] \\
\hline Constant & 0.065848 & [ 1.590$]$ & 0.025662 & [ 0.146$]$ & 1.927393 & [ 1.371$]$ \\
\hline F-test & 14403.51 & $0.000 * *$ & 4644.436 & $0.000 * *$ & 1511.494 & $0.000 * *$ \\
\hline $\mathrm{R}^{2}$ & 0.996 & & 0.990 & & 0.971 & \\
\hline DW Stat. & 1.993 & & 2.008 & & 2.005 & \\
\hline Obs. (N) & 738 & & 738 & & 738 & \\
\hline
\end{tabular}

$* t$ test score in [ ]. ** Significance at $1 \%$ level

\section{Impulse Response Function Analysis}

To view a snapshot of the dynamics of financial markets inter-linkages and for the sake of visual comparison an Impulse Response Function (IRF) analysis is performed. The results are presented in Fig. 1.

\section{IRF Pre-Global Financial Crisis}

It showed that the shock to the global Bonds markets (bonds yield) lead to a persistent decrease in the stock market which started to fade after 4 periods (months). It implies that the increase in the yield which means a drop in the price of bonds, suppresses the stock market. Nevertheless, the stock markets recovered steadily over the remaining period. The shock to the Forex leads to a mild but consistent surge (after initial minute drop) in the stock markets implying that the appreciation of currency (Real Effective Exchange Rate) leads to an increase in the stock market. Perhaps the confidence associated with it and the strength of the currency helps the stock market too. The shock to the stock markets led to an increase in the Bonds yield (decrease in the prices of bonds) implying that the positive development in the stock markets could lead to a drop in the price of the bond as it also indicates an increase in the appetite for the risk associated positive sentiment, investor confidence and financial stability. The 

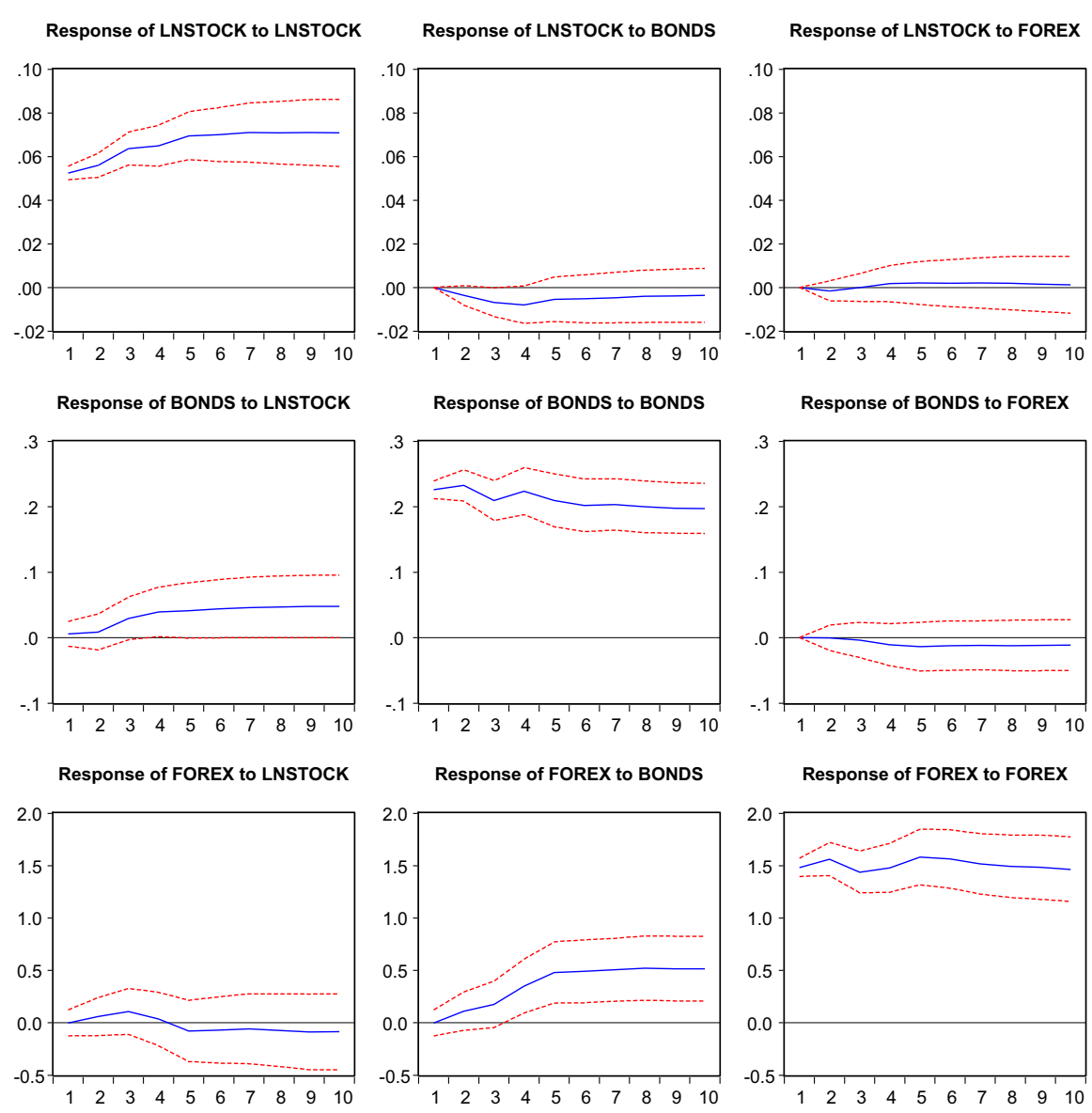

Fig. 1 Impulse response function: Ln-stock, bonds and forex. Response to Cholesky One S.D. Innovations $\pm 2 \mathrm{SE}$

shock to the Forex (REER) led to a very mild decrease in the yield which was not very persistent, implying that the exchange rate appreciation does not really lead to a higher yield on bonds. It also indicated the validity of interest rate parity theory. On the forex market, the shock to the stock market lead to the initial application of the Forex (REER) indicating the appreciation of currency due to stock market surge, however, it reverted after a few periods. The shock to the bond's yield (dropping prices of bonds) lead to initial depreciation and then persistent appreciation of forex, indicating a reversal which might come through the real side (current account improvements) of the economy.

An important point to emphasise here is the loss of significance over longer lags in the VAR model, which is prominent in our IRF analysis. The effort to inclusivly capture the dynamics of the system being modelled is associated with with a risk that, the greater the number of lags, the greater the number of parameters that must be estimated and the fewer the degrees of freedom. Moreover, the presence of several lags of the same variable leads to parameter estimates not being statistically significant (See 

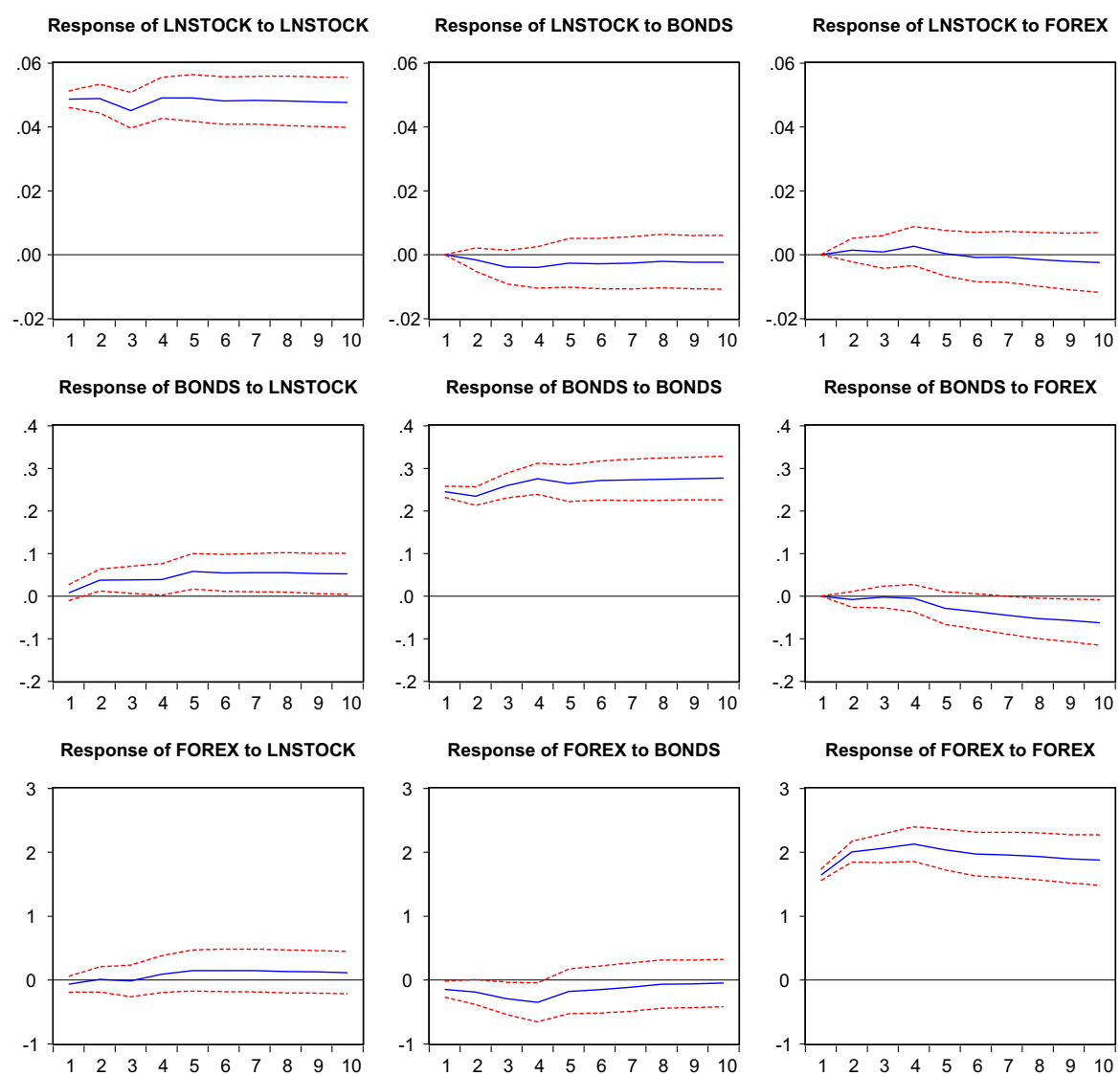

Fig. 2 Impulse response function: Ln-stock, bonds and forex. Response to Cholesky One S.D. Innovations $\pm 2 \mathrm{SE}$

Pindyck and Rubinfeld (1997); Pecican (2010)). Concomitantly, despite the fact that the impact of the explanatory variable does not meet the statistical level of significance, it is still important as we seek to look at this phenomenon in a broader context and make the best judgment based on the central view of tendency.

\section{IRF Post-Global Financial Crisis}

The Fig. 2 showed that the in the Post- GFC world the shock to the Bond markets (yield) lead to the persistent drop in the stock market, implying that the stock market responds negatively to the increase in the yield of bonds (drop in bonds prices). It reflects the importance of the bonds markets for the stock market as the sovereign debt processes the risks which are also significant for the equity market. The shock to the Forex lead to the initial surge in the stock market which persisted for a few months and then faded, indicating a surge in the stock market due to the exchange rate appreciation. The Bond markets (yield) showed an increase in response to the surge in the stock market, implying that the increase in the stock market lead to the drop in the bonds prices, which is intuitive in the context that the financial stability and scenario 
where the stock markets are booming could lead to the drop in the prices of bonds due to the portfolio adjustments. The shock to the forex showed that the increase in the Forex lead to a drop in yield and an increase in the bond prices, implying that the increases in the prices of bonds as the exchange rate strength and once again indicates that interest rate parity holds.

The Forex market showed that the positive shock to the stock market lead to an appreciation of exchange rate which persisted over a period of time. The Bonds (yield) also showed that the positive shock to the yield lead to a decrease in the exchange rate (REER) implying the negative effect of the bonds (yield) on the Forex markets. It is intuitive as the increased yield implies falling bond prices and increases in the risk premium on bonds which could lead to a depreciation of currency as well.

\section{Pre and Post GFC comparison}

The comparative analysis by putting the results in Figs. 1 and 2 together showed that although the stock markets responded negatively to increased bond yields in both periods, in the post-crises world the response was rather sharper. Similarly, the stock market responded positively to Forex shocks (REER appreciation) in the pre as well as post crises regimes, but in the post-crises regime it was sharper and faded quickly.

The Bond market showed that in the pre-crises the shock to the stock markets lead to a drop in the Bonds yield (increase in the prices of bond), but in the post-crisis world, the Bond markets (yield) increased in response to the surge in the stock market. This result showed the increase in the stock market lead to an increase in the bond yield (decrease in the prices) in the pre-crises world, however, it lead to a more pronounced affect in the post-crises regime. It indicates that there has not been a shift in the relationship, however, the results became more significant. In the pre-crises regime, the shock to the Forex lead to a very mild increase in the yield, however, it was not very persistent, but in the post-crises period, the shock to the forex showed that the increase in the Forex lead to a drop in yield and an increase in the bond prices which persisted more than before. So, again there was a shift in a relationship which could be associated with the yield hunger among the investors in the post-financial crisis world.

The Pre-GFC era showed that the shock to the stock market led to an initial appreciation of forex which reverted after a few periods. Contrarily, in the post-crisis regime, in response to a similar shock, the Forex market showed appreciation of the exchange rate which persisted over a period of time. Hence there was a shift in the relationship. In the pre-crisis world the shock to the bond's yield (dropping prices of bonds) lead to initial depreciation and thereafter a persistent appreciation of Forex, however in the post-crises era the positive shock to the yield lead to a decrease in the exchange rate implying the negative effect of bond (yield) on the forex markets. It is intuitive as the increased yield implies falling bonds prices and increases in the risk premium on bonds could lead to a depreciation of currency as well.

\section{Integration of National Financial Structure}

In the second half of empirical analysis of this study, we analysed the dynamics of association between the British financial sector (constituted of Stock, Bonds and Forex 
markets) and major global financial sectors i.e. USA, Germany, China, Japan, India, Brazil, Australia and Canada. The focus on the British financial sector is because the British financial sector has global significance, perhaps as cited earlier, this is the reason it has been put on top of the list in the Global Financial Centre Index (GFCI, 2016). In specific to UK, Gregoriou et al. (2009) found a structural break in the response of the stock market to monetary policy in the post-financial crisis (2008) period. Concomitantly, it raises questions of whether the association between British financial markets and major global financial markets have also been changed due to the financial crises and if so there could implications for economic policies as well as investment strategies. At this juncture, we have nine variables of interest for analysis which include nine countries with three financial markets (stock, bond and Forex) constituting the financial sector of each country as a proxy. We did so by using the same data as used in the "Global Financial Markets" section, however now we had 3 crosssections for each country representing three markets and together forming the financial sector of that country. The Panel VAR model will take the form of following equations:-

$$
\ln U K \text { fin }_{i, t}=\alpha_{10}+\sum_{j=1}^{p} \beta_{1 j} \ln \text { Globalfin }_{i, t-j}+\varepsilon_{1 i, t}
$$

Where the Globalfin is the global financial sector including 9 countries financial sector. To start with the data was tested for stationarity. The results summary of stationarity test for the Panel Unit Root showed that although at level there were mixed results, on the first difference $I$ (1) all the panel data was stationary. Hence, in the Panel VAR model, we use the first differenced data. Thereafter an optimal lag selection test is performed using various criteria and the co-integration test using Pedroni Residual approach. The results suggested that there was no co-integration relationship found at $5 \%$ level of significance. ${ }^{8}$ Concomitantly, the unrestricted Panel VAR model was chosen. In line with the previous practice in first part of the analysis (4.2) we split the under analysis period into Pre-and Post-GFC eras.

\section{VAR Model Pre-Global Financial Crisis}

At first, we estimated for Panel VAR model i.e. Eq. 5 using Panel Ordinary Least Squared method (Table 3).

The results of our Panel VAR model (Eq. 5) estimated for the Pre-GFC period showed that there are several values of coefficients ranging from positive to negative and significant to insignificant. The $t$ test score parallel to each coefficient value indicates a significant impact of explanatory variables at $95 \%$ level of confidence. The F-test score was quite high and significant as well as the goodness of fit $\mathrm{R}^{2}$. For the Post-GFCs period the PVAR model (Eq. 5) is also estimated.

\footnotetext{
8 In order to conserve the space, the results of the unit root, optimal lag selection and co-integration test using approaches similar to "Global Financial Markets" section are not presented here but are available on request.
} 
Table 3 Panel vector autoregressive (PVAR) Model M1-2003: M8- 2008

\begin{tabular}{|c|c|c|c|c|}
\hline Variables & Coefficients & Standard errors & T-statistics & P-values \\
\hline UKt-1 & 0.510 & 0.079 & 6.465 & 0.000 \\
\hline UKt-2 & 0.265 & 0.070 & 3.791 & 0.000 \\
\hline Australiat-1 & 0.390 & 0.080 & 4.885 & 0.000 \\
\hline Australiat-2 & -0.003 & 0.071 & -0.037 & 0.971 \\
\hline Brazilt-1 & -0.210 & 0.062 & -3.378 & 0.001 \\
\hline Brazilt-2 & 0.161 & 0.064 & 2.536 & 0.012 \\
\hline Canadat-1 & -0.189 & 0.075 & -2.526 & 0.012 \\
\hline Canadat-2 & 0.102 & 0.075 & 1.360 & 0.176 \\
\hline Chinat-1 & -0.473 & 0.124 & -3.809 & 0.000 \\
\hline Chinat-2 & 0.047 & 0.132 & 0.359 & 0.720 \\
\hline Germanyt-1 & -0.196 & 0.190 & -1.032 & 0.304 \\
\hline Germanyt-2 & 0.408 & 0.191 & 2.135 & 0.034 \\
\hline Indiat-1 & -0.284 & 0.066 & -4.328 & 0.000 \\
\hline Indiat-2 & 0.174 & 0.071 & 2.448 & 0.015 \\
\hline Japant-1 & -0.265 & 0.081 & -3.261 & 0.001 \\
\hline Japant-2 & 0.076 & 0.077 & 0.986 & 0.325 \\
\hline USAt-1 & -0.181 & 0.130 & -1.398 & 0.164 \\
\hline USAt-2 & 0.616 & 0.139 & 4.445 & 0.000 \\
\hline Constant & 0.130 & 0.080 & 1.628 & 0.105 \\
\hline $\mathrm{R}^{2}$ & 0.99 & & & \\
\hline F-Test & 81401.55 & & & 0.000 \\
\hline Durbin-Watson stat & 2.200 & & & \\
\hline Obs. (N) & 204 & & & \\
\hline
\end{tabular}

* Estimation using ordinary least squared method

\section{VAR Model Post-Global Financial Crisis}

We estimated the P-VAR for the Post-GFC period. The results are presented in the Table 4 below:

Similar to the pre-GFC period, the results of our Panel VAR model (Eq. 5) estimated for the Post-GFC period showed that there were several values of coefficients ranging from positive to negative and from significant to insignificant. The t- test score parallel to each coefficient value indicates a significant impact of explanatory variables at $95 \%$ level of confidence. The related statistics, including F-test score, the goodness of fit $\left(\mathrm{R}^{2}\right)$ also showed significant values and the Durbin-Watson stat showed value close to 2 indicating the absence of autocorrelation. Moreover, the robustness test using White method for Heteroscedasticity and LM test for auto-correlation also supported the model estimation results. However, to sum up the analysis we need to perform an Impulse Response Analysis to get the bigger picture of association among the explanatory and response variables. 
Table 4 Panel vector autoregressive (PVAR) model M1-2009: M10-2015

\begin{tabular}{|c|c|c|c|c|}
\hline Variables & Coefficients & Standard errors & T-statistics & P-values \\
\hline UKt-1 & 0.901 & 0.063 & 14.359 & 0.000 \\
\hline UKt-2 & -0.076 & 0.065 & -1.181 & 0.239 \\
\hline Australiat-1 & -0.108 & 0.073 & -1.479 & 0.141 \\
\hline Australiat-2 & 0.038 & 0.069 & 0.544 & 0.587 \\
\hline Brazilt-1 & -0.025 & 0.052 & -0.488 & 0.626 \\
\hline Brazilt-2 & 0.091 & 0.056 & 1.617 & 0.107 \\
\hline Canadat-1 & 0.079 & 0.103 & 0.773 & 0.441 \\
\hline Canadat-2 & -0.039 & 0.094 & -0.416 & 0.678 \\
\hline Chinat-1 & -0.180 & 0.113 & -1.596 & 0.112 \\
\hline Chinat-2 & 0.364 & 0.111 & 3.288 & 0.001 \\
\hline Germanyt-1 & -0.181 & 0.109 & -1.663 & 0.098 \\
\hline Germanyt-2 & 0.157 & 0.111 & 1.412 & 0.159 \\
\hline Indiat-1 & 0.161 & 0.055 & 2.916 & 0.004 \\
\hline Indiat-2 & -0.164 & 0.055 & -2.983 & 0.003 \\
\hline Japant-1 & 0.002 & 0.053 & 0.033 & 0.974 \\
\hline Japant-2 & 0.000 & 0.054 & 0.008 & 0.993 \\
\hline USAt-1 & -0.166 & 0.123 & -1.347 & 0.179 \\
\hline USAt-2 & 0.147 & 0.125 & 1.177 & 0.240 \\
\hline Constant & 0.018 & 0.067 & 0.281 & 0.778 \\
\hline $\mathrm{R}^{2}$ & 0.99 & & & \\
\hline F-Test & 54259.69 & & & 0.000 \\
\hline Durbin-Watson stat & 1.948 & & & \\
\hline Obs. (N) & 246 & & & \\
\hline
\end{tabular}

*Estimation using ordinary least squared method

\section{Impulse Response Function Analysis}

To capture the dynamics of UK financial sector linkages with the response to the shocks to the other 8 international financial sectors of under analysis countries, we performed the Impulse Response Function (IRF) analysis. The results are presented below:-

\section{IRF Pre-Global Financial Crisis}

The results of our IRF analysis presented in Fig. 3 below showed the response of the British financial sector to the major global financial sectors. It showed that the one standard deviation shock to the Australian financial sector (which constituted Stock, Bonds and Forex) lead to a positive response from the UK financial sector which persisted for some time. However, a similar shock to the Brazilian, Chinese, Indian and Japanese financial sector lead to the drop in the UK financial sector which also persisted and then recovered gradually. A one standard deviation shock to the Canadian, German and USA financial sector lead to a surge in the UK financial sector. 

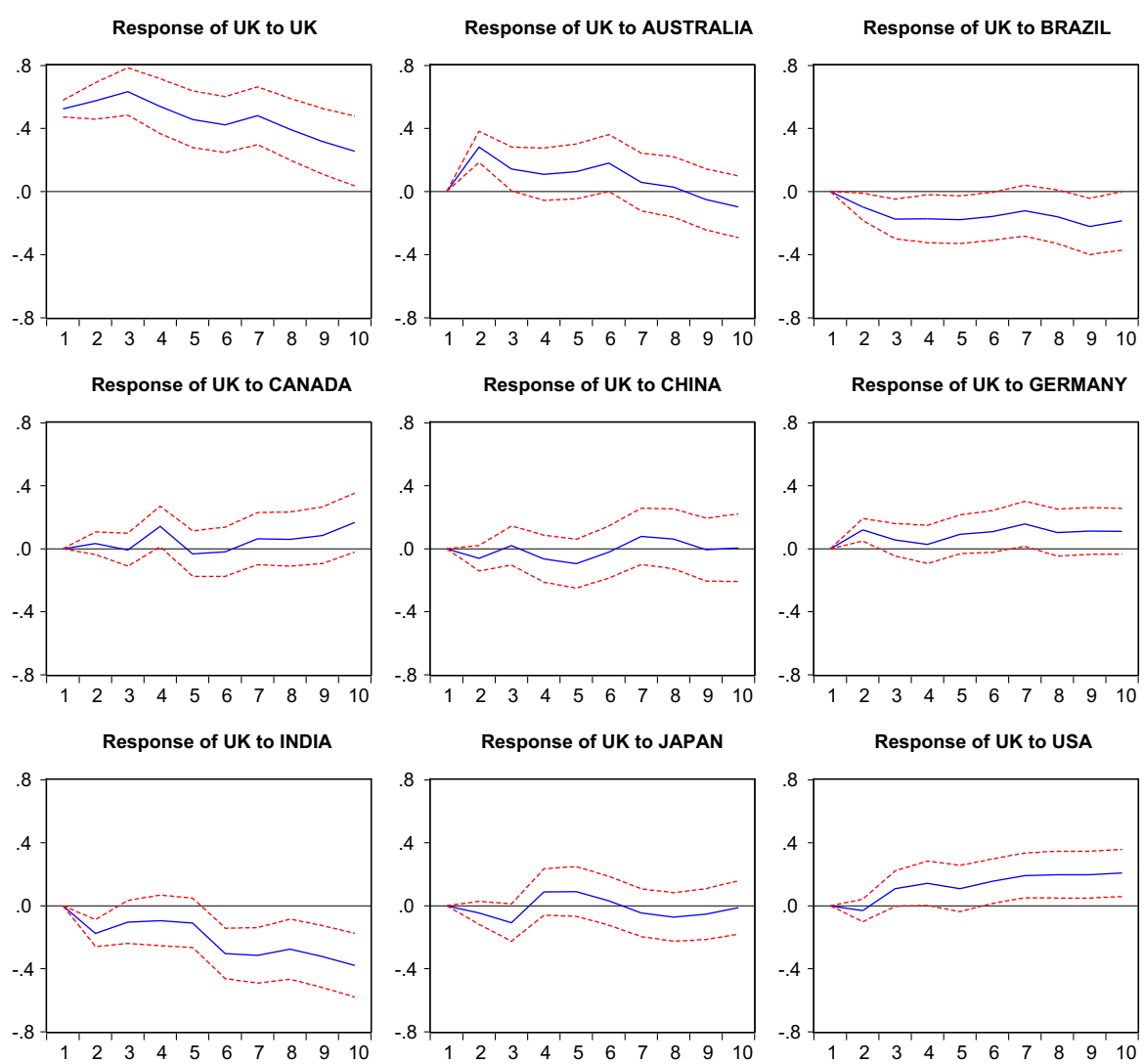

Fig. 3 Impulse response function: Ln-stock, bonds and forex. Response to Cholesky One S.D. Innovations $\pm 2 \mathrm{SE}$

Although the response to German and USA financial sectors was more pronounced and persistent which is intuitive due to their size and significance on the global stage. The results showed a heterogeneity in the response of the UK financial sector to various markets, nevertheless, it seemed that the response was similar to the shock from the developing markets (Brazilian, Chinese, Indian, although it included Japan as well) and the USA, Germany and Canada also showed similar effects. The wider implication is that one needs to take into account the heterogeneity in response.

\section{IRF Post-Global Financial Crisis}

In the Post-GFC period, as shown in the following Fig. 4, a one standard deviation shock to the Australian and German financial sectors lead to a negative response which persisted for a considerable amount of time. The shock to the Brazilian, Canadian, Chinese and Indian markets showed a positive response, although the shock to the Brazil and Canadian financial sectors led to an initial surge but then decrease in the UK financial sector. Shocks to the Chinese and Indian financial sector lead to a prolonged positive development in UK financial sector. The German and USA financial sector shocks lead to an initial negative response from the British financial sector however it recovered in a few periods. 

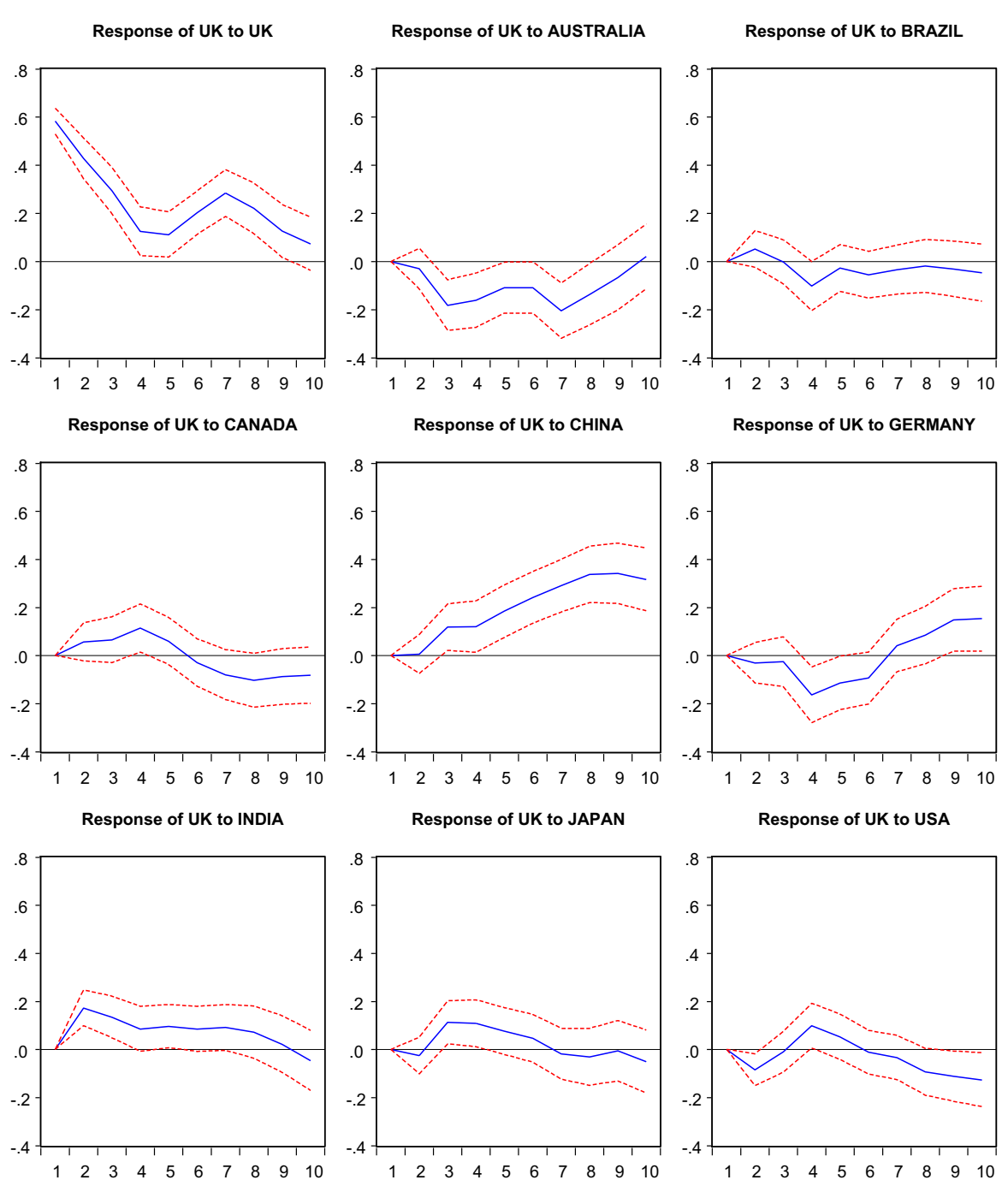

Fig. 4 Impulse response function: Ln-Stock, bonds and forex. Response to Cholesky One S.D. Innovations $\pm 2 \mathrm{SE}$

\section{Pre and Post GFC Comparative Analysis}

The comparative analysis of the Pre and Post GFC world clearly shows that the association among the financial sectors has been changed. The response of the UK financial sector to the German and USA financial sector have become milder. Nevertheless, the emerging markets including China, Brazil and India showed a comparatively more significant impact on the UK financial sector, implying the increased importance of the latter in the recent past. The German and USA financial sector also showed a change in its impact in the pre and post financial crisis world. It showed that these (Germany and USA) financial sectors have become competitive to the UK financial Sector in the 
Post GFC world as the surge in them lead to a relative response from the UK financial sector which could be associated with the portfolio adjustment.

\section{Conclusions and Implications}

Our analysis started with looking at the global financial markets which lead us to conclude that although stock markets responded negatively to increased bond yield in both periods, in the post-crises world the response was rather sharper. Similarly the stock market responded positively to Forex shocks in Pre- as well as post crises regimes, but in the post-crises regime it was sharper and faded quickly. The response of the bond yield to stock market surge has been positive in both pre and post-GFC period, which is premia facie evidence that the positive development in the stock market leads to suppressing the bond prices, however, this effect was rather more pronounced in post-crises regimes. It indicates that there has not been a shift in the relationship in terms of direction but it still has implications in terms of portfolio adjustment and substitution between risky and risk free assets. In the pre-crises regime the shock to the Forex gave a very mild increase in the yield, however, it was not very persistent, implying that the exchange rate appreciation does not really lead to very high yields on bonds, we associated it with validity of interest rate parity theory. However, in the post-crises period, the shock to the forex showed that the increase in the forex lead to a drop in yield and an increase in the bond prices which were comparatively persistent which could be associated with the yield hunger among the investors in the post-financial crisis world.

The pre-crises area showed that the stock market lead to an initial appreciation of Forex which reverted after a few periods. Contrarily, in the post-crisis regime the Forex market showed that the positive shock to the stock market lead to an appreciation of exchange rate which persisted over a period of time. Hence there was a shift in the relationship. In the pre-crisis world the shock to the bond's yield (dropping prices of bonds) lead to initial depreciation and then persistent appreciation of Forex, however in the post-crises ear the positive shock to the yield lead to a decrease in the Forex implying the negative effect of bond yield on the Forex markets. It is intuitive as the increased yield implies falling bond prices and increases in risk premium on bonds which could lead to a depreciation of currency as well.

On the integration among national financial sector, our analysis lead us to conclude that in the Pre and Post GFC the world clearly shows that the association among the financial sectors has been changed. The response of the UK financial sector to the developed financial sectors (German and USA) decreased in its comparative significance in the Post-GFC world. The emerging markets particularly, China, and India showed a rather more significant impact on the UK financial sector implying the increased importance of the latter in the recent past. The German and USA financial sector also showed a change in their impact in the post-financial crisis world with some element of being competitive to the UK financial Sector as the surge in them lead to a relative response from the UK financial sector which could be associated with portfolio adjustment. 
Acknowledgements The authors acknowledge and thank Dr. Jamie Morgan and the participants of the 3rd Vietnam International Conference in Finance for their constructive comments which lead to significant improvement of the original draft.

Open Access This article is distributed under the terms of the Creative Commons Attribution 4.0 International License (http://creativecommons.org/licenses/by/4.0/), which permits unrestricted use, distribution, and reproduction in any medium, provided you give appropriate credit to the original author(s) and the source, provide a link to the Creative Commons license, and indicate if changes were made.

\section{Appendix: A:}

See Tables 5, 6 .

Table 5 Descriptive statistics: data on markets: January 2003 to August 2008
Table 6 Descriptive statistics: data on markets: January 2009 to October 2015

\begin{tabular}{llll}
\hline & BONDS & FOREX & STOCK \\
\hline Mean & 4.792958 & 95.0777 & 10832.83 \\
Median & 4.5295 & 92.27 & 7705.435 \\
Maximum & 17.478 & 129.29 & 72592.5 \\
Minimum & 0.53 & 46.0704 & 1060.74 \\
Std. Dev. & 2.071958 & 16.12724 & 11145.72 \\
Skewness & 1.324877 & -0.09568 & 2.963809 \\
Kurtosis & 8.285901 & 3.212688 & 13.0643 \\
Jarque-Bera & 891.5296 & 2.087301 & 3478.882 \\
Probability & 0.00000 & 0.352167 & 0.0000 \\
Sum & 2933.29 & 58187.55 & 6629690 \\
Sum Sq. Dev. & 2623.029 & 158913.8 & $7.59 \mathrm{E}+10$ \\
Observations & 612 & 612 & 612 \\
\hline
\end{tabular}

\begin{tabular}{llll}
\hline & BONDS & STOCK & FOREX \\
\hline Mean & 3.385484 & 15094 & 98.74698 \\
Median & 3.155 & 9950.855 & 99.30015 \\
Maximum & 9.06 & 70673.3 & 129.183 \\
Minimum & 0.185 & 1979.21 & 63.7739 \\
Std. Dev. & 2.051491 & 15976.96 & 9.796509 \\
Skewness & 1.033184 & 2.072286 & -0.388068 \\
Kurtosis & 3.633304 & 6.326543 & 4.748734 \\
Jarque-Bera & 143.6316 & 868.4836 & 112.559 \\
Probability & 0.000 & 0.000 & 0.000 \\
Sum & 2498.487 & 11139375 & 72875.27 \\
Sum Sq. Dev. & 3101.748 & $1.88 \mathrm{E}+11$ & 70731.06 \\
Observations & 738 & 738 & 738 \\
\hline
\end{tabular}




\section{Appendix: B}

See Tables 7, 8, 9 and 10.

Table 7 Chow test of structural break

Restrictions are linear in coefficients
Part A: Intercept Break

Wald Test:

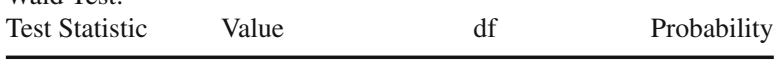

\begin{tabular}{llll}
\hline$t$ statistic & 1.662588 & 1372 & 0.0966
\end{tabular}

$\begin{array}{llll}F \text { statistic } & 2.764200 & (1,1372) & 0.0966\end{array}$

$\begin{array}{llll}\text { Chi-square } & 2.764200 & 1 & 0.0964\end{array}$

Null Hypothesis: $\mathrm{C}(6)=0$

Null Hypothesis Summary:

Normalized Restriction $(=0)$

Value Std. Err.

$\begin{array}{lll}\mathrm{C}(6) & 0.439328 & 0.264243\end{array}$

Part A: Slope Break

Wald Test:

Test Statistic Value df Probability

\begin{tabular}{llll}
\hline F-statistic & 4.659744 & $(2,1372)$ & 0.0096 \\
Chi-square & 9.319487 & 2 & 0.0095
\end{tabular}

Null Hypothesis: $\mathrm{C}(4)=\mathrm{C}(5)=0$

Null Hypothesis Summary:

\begin{tabular}{lll} 
Normalized Restriction $(=0)$ & Value & Std. Err. \\
C $(4)$ & -0.004055 & 0.002525 \\
C $(5)$ & 0.033103 & 0.0145511 \\
\hline
\end{tabular}




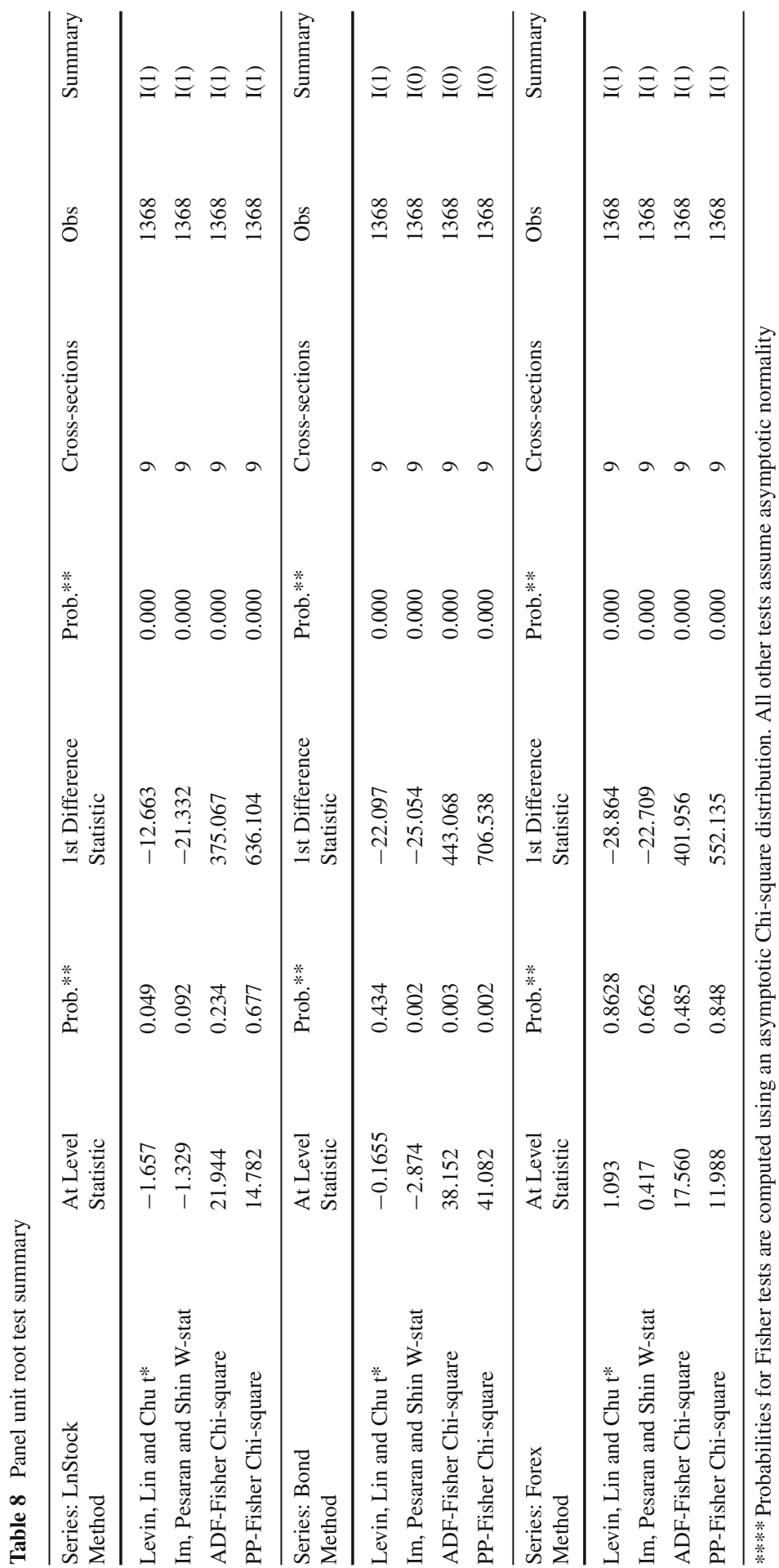


Table 9 Optimal lag selection

\begin{tabular}{lllllll}
\hline Lag & LogL & LR & FPE & AIC & SC & HQ \\
\hline 0 & -4063.0880 & NA & 428.4443 & 14.5738 & 14.5970 & 14.5829 \\
1 & -245.6290 & 7580.1870 & 0.0005 & 0.9234 & $1.016399^{*}$ & $0.959720^{*}$ \\
2 & -238.1951 & 14.6813 & 0.0005 & 0.9290 & 1.0918 & 0.9926 \\
3 & -215.4562 & 44.6628 & 0.0005 & 0.8798 & 1.1123 & 0.9706 \\
4 & -207.2772 & 15.9770 & 0.0005 & 0.8827 & 1.1850 & 1.0008 \\
5 & -190.0412 & $33.48354^{*}$ & $0.000471^{*}$ & $0.853194^{*}$ & 1.2252 & 0.9985 \\
6 & -185.3966 & 8.9730 & 0.0005 & 0.8688 & 1.3105 & 1.0413 \\
\hline
\end{tabular}

* Indicates lag order selected by the criterion (each test at 5\% level). LR sequentially modified LR test statistic, FPE final prediction error, AIC Akaike information criterion, SIC Schwarz information criterion, $H Q$ Hannan-Quinn information criterion

Table 10 Pedroni residual co-integration test

\begin{tabular}{lcllr}
\hline Alternative hypothesis: & \multicolumn{3}{l}{ Weighted } & \\
\cline { 3 - 4 } Common AR coefficients (with in-dimension) & Statistic & Prob. & Statistic & Prob. \\
\hline Panel v-Statistic & -0.353 & 0.638 & -0.353 & 0.638 \\
Panel rho-Statistic & 1.012 & 0.844 & 1.012 & 0.844 \\
Panel PP-Statistic & 0.579 & 0.719 & 0.579 & 0.719 \\
Panel ADF-Statistic & 0.779 & 0.782 & 0.779 & 0.782
\end{tabular}

\begin{tabular}{lcc}
\hline $\begin{array}{l}\text { Alternative hypothesis: } \\
\text { Individual AR coefficients. (between-dimension) }\end{array}$ & Statistic & Prob. \\
\hline Group rho-Statistic & 2.509 & 0.994 \\
Group PP-Statistic & 1.777 & 0.962 \\
Group ADF-Statistic & 2.027 & 0.979
\end{tabular}

*P values; ** Newey-West automatic bandwidth selection and Bartlett kernel

\section{References}

Agenor, P.R., and L.A.P.D. Silva. 2011. Macroeconomic Stability, Financial Stability, and Monetary Policy Rules. International Finance 15 (2): 205-224.

Angelini, P., Neri, S., Panetta, F. 2012. Monetary and macroprudential policies, Working Paper Series 1449, European Central Bank.

Brooks, C. 2008. Introductory Econometrics for Finance, 2nd ed. Cambridge: Cambridge University Press. Benigno, G., H. Chen, C. Otrok, A. Rebucci, and E.R. Young. 2013. Financial Crises and Macro-Prudential Policies. Journal of International Economics 89 (2): 453-470.

Benigno, G. H. Chen, C. Otrok, A. Rebucci, E.R. Young, 2012. Optimal Policy for Macro-Financial Stability, Research Division Federal Reserve Bank of St. Louis, Working Paper 2012-041A.

Berger, A.N., C.H.S. Bouwman, 2012. Bank Liquidity Creation, Monetary Policy, and Financial Crises, Available at SSRN: http://ssrn.com/abstract=1952728

Blanchard, O. G. Dell'Ariccia, P. Mauro, 2010. Rethinking Macroeconomic Policy, IMF staff Position Note, SPN/10/03.

Borio, C. 2011. Rediscovering the macroeconomic roots of financial stability policy: journey, challenges and a way forward, BIS Working Papers No 354. 
Campbell, J.Y. 1995. Some Lessons from Yield Curve. Journal of Economic Prospective 9 (3): 129-152.

Collard, F., H. Dellas, B. Diba, O. Loisel, 2012. Optimal Monetary and Prudential Policies, Bank of France, Working paper No 413.

Chen, M.P., P.F. Chen, and C.C. Lee. 2014. Frontier stock market integration and the global financial crisis. The North American Journal of Economics and Finance 29: 84-103.

Choi, I. 2001. Unit root tests for panel data. Journal of International Money and Finance 20 (2): 249-272.

Choudhry, T., R. Jayasekera, and G. Kling. 2014. The Global Financial Crisis and the European Single Market: The end of integration? Journal of International Money \& Finance 49: 191-196.

Curdia, V., and M. Woodford. 2011. The central-bank balance sheet as an instrument of monetary policy. Journal of Monetary Economics 58: 54-79.

Feldstein, M., and C. Horioka. 1980. Domestic Saving and International Capital Flows. Economic Journal 90 (358): 314-329.

Fischbacher, U., T. Hens, and S. Zeisberger. 2012. The Impact of Monetary Policy on Stock Market Bubbles and Trading Behavior: Evidence from the Lab. Journal of Economic Dynamics and Control 37: 21042122.

Georgoutsos, D.A., and P.M. Migiakis. 2013. European sovereign bond spreads: financial integration and market conditions. Applied Financial Economics 23 (20): 1609-1621.

GFCI 2016. The Global Financial Centres Index 20 available at [http://www.longfinance.net/images/gfci/ 20/GFCI20_26Sep2016.pdf] accessed 9th January 2016.

Gregoriou, A., A. Kontonikas, R. MacDonald, and A. Montagnoli. 2009. Monetary Policy Shocks and Stock Returns: Evidence from the British Market. Financial Markets and Portfolio Management 23 (4): 401-410.

Gupta, R., and F. Guidi. 2012. Co-integration relationship and time varying co-movements among Indian and Asian developed stock markets. International Review of Financial Analysis 21: 10-22.

Hadri, K. 2002. Testing for stationarity in heterogeneous panel data. The Econometrics Journal 3 (2): $148-161$.

Im, K.S., M.H. Pesaran, and Y. Shin. 2003. Testing for unit roots in heterogeneous panels. Journal of Econometrics 115 (1): 53-74.

Ioannidis, C., and A. Kontonikas. 2008. The impact of monetary policy on stock prices. Journal of Policy Modelling 30: 33-53.

Kizys, R., and C. Pierdzioch. 2009. Changes in the international co-movement of stock returns and asymmetric Macroeconomic shocks, Int. Fin. Markets. International Financial Markets, Institutions \& Money 19: 289-305.

Kontonikas, A., R. MacDonald, and A. Saggu. 2013. Stock market reaction to fed funds rate surprises: State dependence and the financial crisis. Journal of Banking \& Finance 37 (11): 4025-4037.

Levin, A., C.F. Lin, and C.-S.J. Chu. 2002. Unit root tests in panel data: asymptotic and finite-sample properties. Journal of Econometrics 108 (1): 1-24.

Liew, V.K.S. 2004. Which lag length selection criteria should we employ? Economics Bulletin 3 (33): 1-9.

Lu, X., and F. In. 2006. Monetary Policy, Open Market Operations and New Zealand Interest-Rate and Exchange-Rate Markets, Journal of the Asia Pacific Economy 11: 462-481.

Maddala, G.S., and S. Wu. 1999. A Comparative Study of Unit Root Tests with Panel Data and a New Simple Test. Oxford Bulletin of Economics and Statistics 61 (S1): 631-652.

Mishkin F.S. 2011. Monetary Policy Strategy: Lessons from the Crisis, National Bureau of Economic Research, Working Paper 16755.

Nashier, T. 2015. Financial integration between BRICS and developed stock markets. International Journal of Business and Management Invention 4 (1): 65-71.

Nasir, M.A., and A.M. Soliman. 2014. Aspect of policy combination \& effects on financial markets. Economic Issues 19, 92-118.

Nasir, M., F. Ahmed, M. Ahmed, and J. Wu. 2015. Financial and economic stability as 'two sides of a coin': Non-crisis regime evidence from the UK based on VECM. Journal of Financial Economic Policy 7 (4): 327-353.

Nasir, M.A., A.M. Soliman, M. Yago, J. Wu 2016. Macroeconomic Policies Interaction \& the Symmetry of Financial Markets' Responses. Journal of Central Banking Theory and Practice 5(1): 53-69.

Pecican, E.S. 2010. Forecasting based on open VAR model. Romanian Journal of Economic Forecasting 13 (1): 59-69.

Pedroni, P. 1999. Critical Values for Cointegration Tests in Heterogeneous Panels with Multiple Regressors, You have full text access to this content. Oxford Bulletin of Economics and Statistics 61 (S1): 653-670. 
Perron, P. 1989. The great crash, the oil price shock and the unit root hypothesis. Econometrica 57: 13611401.

Pindyck, R.S., and D. Rubinfeld. 1997. Econometric Models and Econometric Forecasts. Boston: Irwin McGraw Hill Publishing Co.

Ranganathan, T., Ananthakumar, U. (2010).Unit Root Test: Give It A Break, The 30th International Symposium on Forecasting, International Institute of Forecasters

Semiromi, B., and M. Reza. 2010. Literatures about Asset Price Bubbles and Monetary Policies. International Conference on Applied Economics, ICOAE 2010: 695-703.

Svensson, L.E.O. 2012. The Relation between Monetary Policy and Financial Policy. International Journal of Central Banking 8: 293-295.

Wang, S., and D.G. Mayes. 2012. Monetary policy announcements and stock reactions: An international comparison. The North American Journal of Economics and Finance 23: 145-164.

Williams, N. 2012. Monetary Policy under Financial Uncertainty. Journal of Monetary Economics 59 (5): 449-465.

Wong, W.K., H. Khan, and K. Du, J . 2006. Do the interest rates matter for stock prices? An economic study of Singapore \& U.S.A. The Singapore Economic Review 51: 31-51. 